\title{
Prevention of Cardiac Surgery-Associated Acute Kidney Injury
}

\section{A Review of Current Strategies}

\author{
Kirolos A. Jacob, MD, PhD ${ }^{a, *}$, David E. Leaf, MD, MMSc ${ }^{b}$
}

\section{KEYWORDS}

- Acute kidney injury • Prevention • Perioperative care • Inflammation

- Cardiac surgery • Randomized controlled trial

\section{KEY POINTS}

- Most large randomized controlled trials in cardiac surgery-associated acute kidney injury have been negative.

- Encouraging results have been shown with administration of glucocorticoids preoperatively, leukocyte filtration, and inhaled nitric oxide intraoperatively, and implementation of a postoperative Kidney Disease: Improving Global Outcomes bundle of care.

- Future trials should use more precise phenotyping of patients to more accurately identify subgroups of patients most likely to benefit from various interventions.

\section{INTRODUCTION}

Cardiac surgery is one of the most common surgical procedures performed worldwide. $^{1}$ Technological advances and protocolized perioperative patient care have resulted in major improvements in clinical outcomes, including mortality. Despite these improvements, multiple postoperative complications, including atrial fibrillation, myocardial infarction, and stroke, remain common after cardiac surgery, and are associated with significant morbidity and mortality. ${ }^{2}$

Acute kidney injury (AKI) is a common and often devastating complication of cardiac surgery. The reported incidence of cardiac surgery-associated AKI (CS-AKI) depends on the characteristics of the patient population, as well as on the definition used for

Conflict of Interest: None declared.

a Department of Cardiothoracic Surgery, University Medical Center Utrecht, Mail Stop E03.511, PO Box 85500, Utrecht 3508 GA, the Netherlands; ${ }^{b}$ Division of Renal Medicine, Brigham and Women's Hospital, 75 Francis Street, Medial Research Building Room MR416B, Boston, MA 02115, USA

* Corresponding author.

E-mail address: k.a.jacob@umcutrecht.nl 
AKI. Mild forms of CS-AKI occur in up to $30 \%$ of patients undergoing cardiac surgery, ${ }^{3}$ whereas CS-AKI requiring dialysis occurs in only approximately $1 \%$ of patients, but is associated with a markedly increased risk of death. ${ }^{4-6}$ Patients who recover from an episode of CS-AKI remain at greatly increased risk of incident and progressive chronic kidney disease. . $^{3,9}$

Various consensus-based definitions have been proposed for AKI, and are summarized in Table 1. Known risk factors for CS-AKI include advancing age, diabetes mellitus, preoperative chronic kidney disease (often defined as an estimated glomerular filtration rate of $<60 \mathrm{~mL} / \mathrm{min} / 1.73 \mathrm{~m}^{2}$ ), and type of surgery, with open chamber procedures and reoperations corresponding with a higher risk of AKI. Among these risk factors, chronic kidney disease likely has the greatest prognostic value. ${ }^{4,7,10}$

Numerous studies have attempted to determine the factors and mechanisms that cause CS-AKI. Pathways that have been proposed include the systemic inflammatory response, hemolysis-induced injury, as well as ischemia-reperfusion injury caused by oxidative stress perioperatively. . $^{3,7,11-13}$ It is likely that a combination of more than one of these factors, together with patient-related predisposing risk factors, is responsible for CS-AKI in any given patient.

\begin{tabular}{|c|c|c|}
\hline \multirow[b]{2}{*}{ Classification } & \multicolumn{2}{|c|}{ Definitions of AKI Incidence and Severity } \\
\hline & Based on Changes in $\mathrm{SCr}$ & Based on Changes in UOP \\
\hline RIFLE & $\begin{array}{l}\text { Definition: Increase in } \mathrm{SCr} \geq 1.5 \times \text { or } \\
\text { decrease in GFR } \geq 25 \% \text { within } 7 \mathrm{~d} \\
\text { Risk (R): Increase in } \mathrm{SCr} \geq 1.5 \times \text { or } \\
\text { decrease in GFR } \geq 25 \% \\
\text { Injury (I): Increase in } \mathrm{SCr} \geq 2 \times \text { or } \\
\text { decrease in GFR } \geq 50 \% \\
\text { Failure (F): Increase in } \mathrm{SCr} \geq 3 \times \text { or } \\
\text { decrease in GFR } \geq 75 \% \text {, or } \\
\mathrm{SCr}>4 \mathrm{mg} / \mathrm{dL} \text { with an acute } \\
\text { increase }>0.5 \mathrm{mg} / \mathrm{dL}\end{array}$ & $\begin{array}{l}\text { Definition: UOP }<0.5 \mathrm{~mL} / \mathrm{kg} \text { per hour } \\
\text { for } \geq 6 \mathrm{~h} \\
\text { Risk }(\mathrm{R}) \text { : UOP }<0.5 \mathrm{~mL} / \mathrm{kg} \text { per hour } \\
\text { for } \geq 6 \mathrm{~h} \\
\text { Injury }(\mathrm{I}) \text { : UOP }<0.5 \mathrm{~mL} / \mathrm{kg} \text { per hour } \\
\text { for } \geq 12 \mathrm{~h} \\
\text { Failure }(\mathrm{F}) \text { : UOP }<0.3 \mathrm{~mL} / \mathrm{kg} \text { per } \\
\text { hour for } \geq 24 \mathrm{~h} \text { or anuria for } \\
\quad \geq 12 \mathrm{~h}\end{array}$ \\
\hline AKIN & $\begin{array}{l}\text { Definition: Increase in } \mathrm{SCr} \geq 0.3 \mathrm{mg} / \mathrm{dL} \\
\text { or } \geq 1.5 \mathrm{x} \text { within }<48 \mathrm{~h} \\
\text { Stage } 1 \text { : Increase in } \mathrm{SCr} \geq 0.3 \mathrm{mg} / \mathrm{dL} \\
\text { or } \geq 1.5 \times \\
\text { Stage } 2: \text { Increase in } \mathrm{SCr} \geq 2 \times \\
\text { Stage } 3 \text { : Increase in } \mathrm{SCr} \geq 3 \times \text {, or } \\
\mathrm{SCr}>4 \mathrm{mg} / \mathrm{dL} \text { with an acute } \\
\text { increase }>0.5 \mathrm{mg} / \mathrm{dL} \text {, or RRT }\end{array}$ & $\begin{array}{l}\text { Definition: UOP }<0.5 \mathrm{~mL} / \mathrm{kg} \text { per hour } \\
\text { for } \geq 6 \mathrm{~h} \\
\text { Stage } 1 \text { : UOP }<0.5 \mathrm{~mL} / \mathrm{kg} \text { per hour } \\
\quad \text { for } \geq 6 \mathrm{~h} \\
\text { Stage } 2 \text { : UOP }<0.5 \mathrm{~mL} / \mathrm{kg} \text { per hour } \\
\text { for } \geq 12 \mathrm{~h} \\
\text { Stage } 3 \text { : UOP }<0.3 \mathrm{~mL} / \mathrm{kg} \text { per hour } \\
\text { for } \geq 24 \mathrm{~h} \text { or anuria for } \geq 12 \mathrm{~h}\end{array}$ \\
\hline KDIGO & $\begin{array}{l}\text { Definition: Increase in } \mathrm{SCr} \geq 0.3 \mathrm{mg} / \mathrm{dL} \\
\text { within } 48 \mathrm{~h} \text { or } \geq 50 \% \text { within } 7 \mathrm{~d} \\
\text { Stage } 1: \text { Increase in } \mathrm{SCr} \geq 0.3 \mathrm{mg} / \mathrm{dL} \\
\text { or } \geq 1.5 \times \\
\text { Stage } 2 \text { : Increase in } \mathrm{SCr} \geq 2 \times \\
\text { Stage } 3 \text { : Increase in } \mathrm{SCr} \geq 3 \times \text {, or } \\
\mathrm{SCr}>4 \mathrm{mg} / \mathrm{dL} \text {, or } \mathrm{RRT}\end{array}$ & $\begin{array}{l}\text { Definition: UOP }<0.5 \mathrm{~mL} / \mathrm{kg} \text { per hour } \\
\text { for } \geq 6 \mathrm{~h} \\
\text { Stage } 1 \text { : UOP }<0.5 \mathrm{~mL} / \mathrm{kg} \text { per hour } \\
\quad \text { for } \geq 6 \mathrm{~h} \\
\text { Stage } 2 \text { : UOP }<0.5 \mathrm{~mL} / \mathrm{kg} \text { per hour } \\
\text { for } \geq 12 \mathrm{~h} \\
\text { Stage } 3 \text { : UOP }<0.3 \mathrm{~mL} / \mathrm{kg} \text { per hour } \\
\text { for } \geq 24 \mathrm{~h} \text { or anuria for } \geq 12 \mathrm{~h}\end{array}$ \\
\hline
\end{tabular}

RIFLE was adopted in 2004 by the Acute Dialysis Quality Initiative. AKIN was adopted in 2007 by the Acute Kidney Injury Network. KDIGO was adopted in 2012 by the KDIGO AKI Work Group.

Abbreviations: KDIGO, Kidney Disease Improving Global Outcomes; RIFLE, Risk, Injury, Failure, Loss, and End-stage renal disease; SCr, serum creatinine; UOP, urine output. 
Although CS-AKI is an important problem on its own, it is also an excellent model for studying novel therapeutic agents and strategies for AKI prevention in humans in general. Accordingly, many randomized controlled trials (RCTs) have been performed to investigate strategies for prevention of CS-AKI. In this review, we summarize these various strategies, including their rationale and their findings.

\section{METHODS}

We searched Medline via Pubmed and the Cochrane Database of Systematic Reviews via Ovid for RCTs investigating strategies targeting CS-AKI in patients undergoing cardiac surgery. We restricted our search to, double-blind RCTs published since January 1,2000 , that enrolled a minimum of 100 adult patients ( $>18$ years of age). Studies focused on contrast-induced nephropathy, and those studying patients undergoing emergency cardiac surgery were excluded. We categorized the therapeutic strategies into 3 groups according to the time period of therapeutic intervention: preoperative, intraoperative, and postoperative.

The following information was extracted from each article: study design (including blinding and use of placebo), mean age, sample size, type of surgery (coronary artery bypass grafting, valve, or combined surgery), AKI definition used, intervention, and outcome.

\section{PREOPERATIVE INTERVENTIONS}

A variety of preoperative interventions have been studied for prevention of CS-AKI, including corticosteroids, remote ischemic preconditioning (RIPC), N-acetylcysteine (NAC), and statins. Major RCTs conducted in this area that included 100 or more patients are summarized in Table 2.

\section{Corticosteroids}

\section{Rationale}

Cardiac surgery and cardiopulmonary bypass (CPB) invariably cause an acute systemic inflammatory response syndrome (SIRS). ${ }^{11,14}$ Release of key cytokines, including IL-6, IL-8, complement C3/C4, and tumor necrosis factor- $\alpha$ are characteristic of SIRS and may contribute importantly to postoperative AKI. ${ }^{7,11,15,16}$ Corticosteroids are potent anti-inflammatory drugs. In the cardiac surgery setting, corticosteroids have been extensively investigated in preventing both renal and extrarenal postoperative complications.

\section{Findings}

A 2011 Cochrane database systematic review on the use of steroids in cardiac surgery included 54 relatively small RCTs (total of 3615 patients). It concluded that corticosteroids had no beneficial effect on CS-AKI. ${ }^{17}$ After this review, 2 large RCTs were conducted: The DExamethasone in Cardiac Surgery (DECS) $(\mathrm{N}=4494),{ }^{18}$ and the Steroids In caRdiac Surgery (SIRS) $(\mathrm{N}=7507) .{ }^{19}$ Both studies concluded that steroids had no protective effect on AKI postoperatively. The DECS trial used the Failure stage of the Risk, Injury, Failure, Loss, and End-stage renal disease criteria for diagnosing $\mathrm{AKI}$ and the SIRS trial used Kidney Disease: Improving Global Outcomes (KDIGO) stage 3. ${ }^{18,19}$ A recent meta-analysis that included both of these large RCTs found that steroids had no beneficial effect on prevention of CS-AKI in more than 16,000 cardiac surgical patients. Specifically, KDIGO stage 3 AKI occurred with an incidence of $2.7 \%$ (172 of 6330 patients) in the steroid group and in 3.3\% (207 of 6336 patients) in the control group (relative risk, $0.83 ; 95 \%$ confidence interval, 


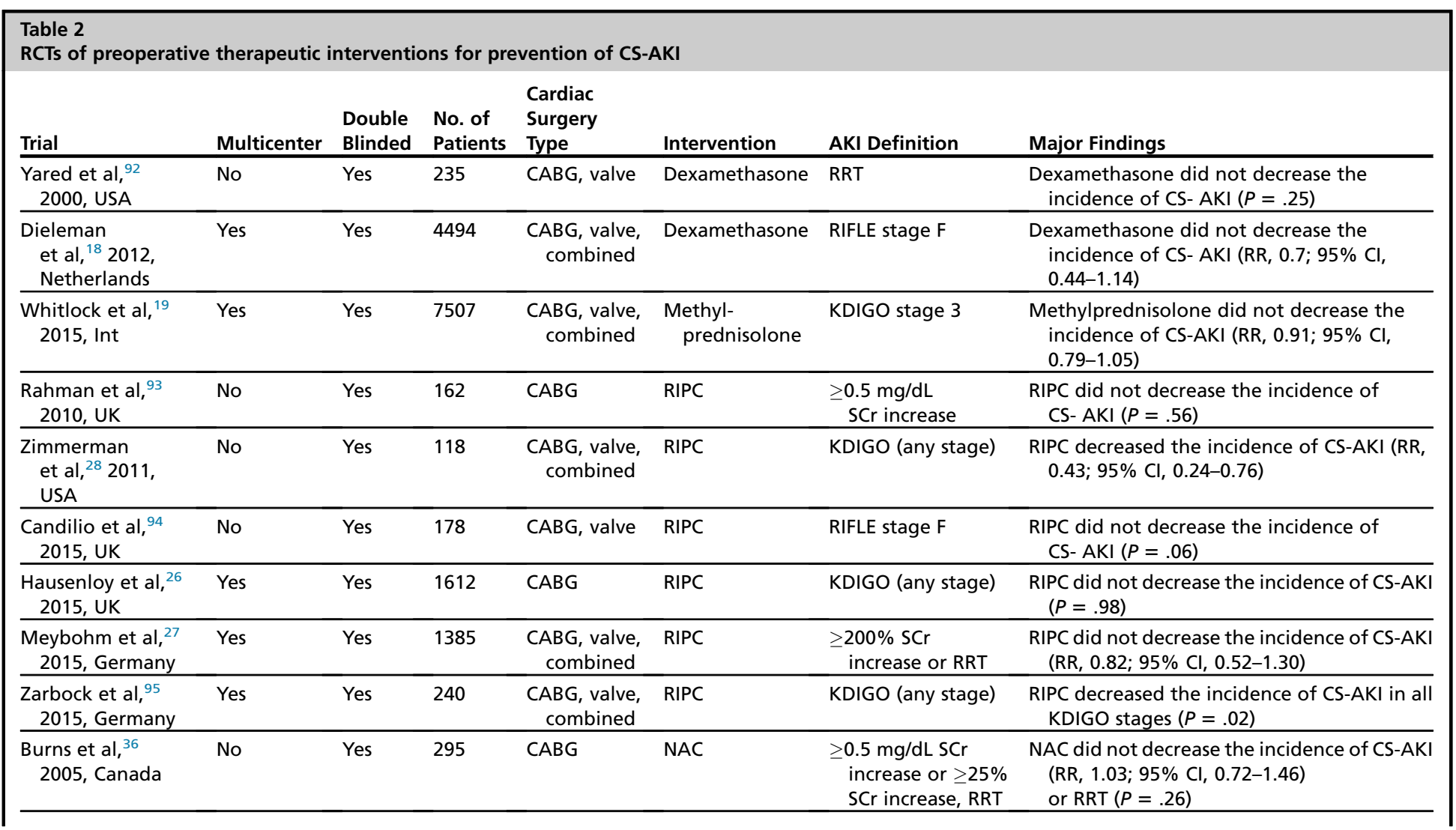




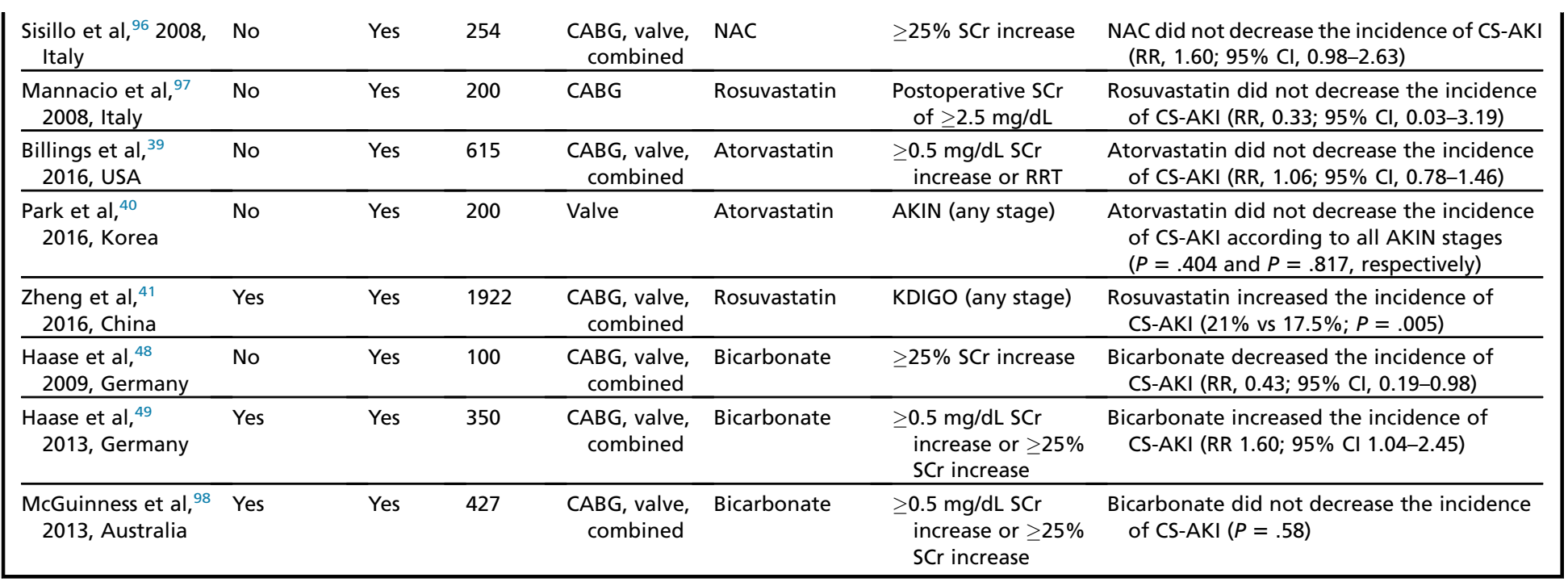

Abbreviations: AKIN, Acute Kidney Injury Network; CABG, coronary artery bypass grafting; Cl, confidence interval; Int, international; KDIGO, Kidney Disease Improving Global Outcome; NAC, $N$-acetylcysteine; RIFLE, Risk, Injury, Failure, Loss, and End-stage renal disease; RR, relative risk; SCr, serum creatinine. 
$\left.0.68-1.01 ; P=.07 ; I^{2}=0 \%\right) .{ }^{20}$ Of note, a major limitation in the definition used for AKI in the DECS trial was the failure to consider renal replacement therapy (RRT), which could have resulted in misclassification. A post hoc analysis of the DECS trial that assessed $A K I$ requiring $R R T$ found that dexamethasone was indeed effective in preventing CS-AKI (relative risk, 0.44; 95\% confidence interval, 0.19-0.96). ${ }^{21}$ This study illustrates the need for careful consideration of appropriate end points in RCTs that assess AKI prevention, and particularly the need for inclusion of RRT in the definition of $\mathrm{AKI} .^{22}$

\section{Bottom line}

Taken in aggregate, there is currently insufficient evidence to recommend routine prophylactic administration of steroids to patients undergoing cardiac surgery for prevention of AKI. Furthermore, a one-size-fits-all approach with respect to steroids (as well as other interventions) fails to take into account the heterogeneity of patient and surgical factors that predispose to AKI. Carefully conducted subgroup analyses may reveal key characteristics that identify patients most likely to benefit from steroids and other interventions.

\section{Remote Ischemic Preconditioning}

\section{Rationale}

RIPC involves brief induction of ischemia and reperfusion to distal tissues, usually by using a sphygmomanometer in the upper arm or leg. This ischemia-reperfusion could result in protection from future ischemia-reperfusion injury, because the first episode of ischemia-reperfusion leads to the release and activation of anti-inflammatory cytokines and oxidative stress scavengers. RIPC has shown promising results in animal models as well as various clinical settings. ${ }^{23-25}$ Therefore, unsurprisingly, RIPC has been advocated as a strategy for prevention of CS-AKI.

\section{Findings}

Multiple RCTs have been conducted to investigate the effect of RIPC on CS-AKI, and have shown inconsistent results. ${ }^{23,26-28}$ One trial conducted in 120 patients found that RIPC decreased the incidence of CS-AKI, as diagnosed by KDIGO stage $1 .{ }^{28} \mathrm{Howev-}$ er, the 2 largest trials (each included $>1500$ patients) concluded that RIPC did not affect the incidence of more severe CS-AKI (KDIGO stage 3). ${ }^{26,27}$ Two metaanalyses concluded that RIPC compared with a sham intervention did not lead to differences in postoperative serum creatinine levels, incidence of AKI, need for RRT, or probability of death. ${ }^{29,30}$

\section{Bottom line}

RIPC, at least for the time being, cannot be recommended for prevention of CS-AKI.

\section{N-Acetylcysteine}

\section{Rationale}

NAC is a precursor of intracellular glutathione, a tripeptide antioxidant that scavenges reactive oxygen species. NAC has been shown to prevent or attenuate $\mathrm{AKI}$ in animal models. ${ }^{31-33}$ Early studies in humans also suggested a protective effect of NAC in the setting of contrast nephropathy, ${ }^{34}$ although a more recent study of 4993 patients found no effect on major adverse kidney events at 90 days. ${ }^{35}$

\section{Findings}

Several small RCTs have evaluated the efficacy of NAC in preventing CS-AKI. The largest study randomly assigned 148 individuals to NAC and 147 individuals to 
placebo, and found that NAC did not prevent postoperative renal dysfunction. ${ }^{36}$ Recent meta-analyses have also failed to demonstrate a significant protective effect of NAC in preventing CS-AKI. ${ }^{37,38}$

\section{Bottom line}

Use of NAC for the prevention of CS-AKI is not supported by current evidence.

\section{Statins}

\section{Rationale}

The 3-hydroxy-3-methyl-glutaryl-CoA reductase inhibitors, also known as statins, attenuate inflammation and oxidative stress, 2 of the possible underlying mechanisms responsible for CS-AKI.

\section{Findings}

Three recent large RCTs found that high-dose perioperative administration of atorvastatin compared with placebo did not decrease the incidence of CS-AKI, either in patients naive to statins or in patients already taking statins. ${ }^{39-41}$ Several meta-analyses of RCTs have also been performed to evaluate the effects of statins given in the preoperative and postoperative period on the incidence of CS-AKI, and none have shown beneficial effects of these drugs. ${ }^{42-44}$ Noteworthy, a meta-analysis by Putzu and colleagues ${ }^{45}$ found that preoperative statins were associated with a possible increased risk of $\mathrm{AKI}$ postoperatively.

\section{Bottom line}

These results do not support the initiation of statin therapy to prevent CS-AKI.

\section{Sodium Bicarbonate}

\section{Rationale}

At neutral or alkaline $\mathrm{pH}$, free ferric ions precipitate as insoluble ferric hydroxide, which is excreted as an inert complex in the urine. A higher urinary $\mathrm{pH}$ also reduces the generation of injurious hydroxyl radicals and lipid peroxidation. ${ }^{46}$ In a murine model of acute renal failure induced by bilateral renal artery occlusion, animals that received sodium bicarbonate to increase the renal tubular $\mathrm{pH}$ were protected against tubular injury. ${ }^{47}$ Thus, urinary alkalinization with sodium bicarbonate might protect against CS-AKI.

\section{Findings}

One RCT that enrolled 100 patients found that the administration of sodium bicarbonate attenuated the severity of CS-AKI, as indicated by a smaller increase in urinary neutrophil gelatinase-associated lipocalin postoperatively. ${ }^{48,49} \mathrm{~A}$ study by the same group a couple of years later in 350 patients showed that bicarbonate administration resulted in a greater incidence of CS-AKI. ${ }^{49}$ Hence, whether administering intravenous sodium bicarbonate prevents CS-AKI remains uncertain, however, because published RCTs have yielded discordant results. Moreover, 3 meta-analyses, the largest of which included more than 1000 patients from $5 \mathrm{RCTs}$, did not demonstrate any benefit of sodium bicarbonate administration. ${ }^{50-52}$

\section{Bottom line}

The use of perioperative administration of sodium bicarbonate for the prevention of CS-AKI is questionable. Larger studies are needed to determine its potential efficacy. It is possible that sodium bicarbonate could be particularly helpful to a subpopulation 
of patients undergoing cardiac surgery who have longer CPB times, and thus more hemolysis and release of free hemoglobin $(\mathrm{Hb})$ and iron. ${ }^{13,53}$

\section{INTRAOPERATIVE MEASURES}

A variety of intraoperative interventions have been studied for prevention of CS-AKI, including off-pump surgery, leukocyte filtration, inotropes and volatile anesthetics. Major RCTs conducted in this area that included 100 or more patients are summarized in Table 3.

\section{On-Pump Versus Off-Pump Coronary Artery Bypass Grafting}

\section{Rationale}

The use of the CPB results in a systemic inflammatory response influencing the function of multiple organs throughout the body, including the kidneys, lungs, and the heart itself. Contact of blood with foreign surfaces such as the CPB circuit, the use of cardiotomy suction, blood-air interface, and surgical trauma and stress are regarded as the main pathophysiologic determinants of this condition. ${ }^{14}$ Consequently, the effect of on-pump versus off-pump CPB on postoperative outcomes, including AKI, has been an area of active investigation.

\section{Findings}

The 3 largest RCTs to date (the CORONARY, GOPCABE, and ROOBY studies) that investigated on-pump versus off-pump CPB enrolled nearly 10,000 patients in total. ${ }^{54-56}$ The CORONARY study enrolled 4752 patients and found no significant difference in the incidence of postoperative $A K I$ requiring RRT between patients undergoing on-pump versus off-pump CPB. ${ }^{54} \mathrm{~A}$ detailed analysis showed that off-pump surgery did decrease the incidence of mild AKI at 30-days (defined as a relative increase in serum creatinine of $>50 \%$ or an absolute increase of $\geq 0.3 \mathrm{mg} / \mathrm{dL}$ ), but the beneficial effects on renal function did not persist at 1 year of follow-up. ${ }^{57}$ Further, neither the ROOBY nor the GOPCABE study showed any renoprotective effects of off-pump compared with on-pump CABG surgery. ${ }^{55,56}$

\section{Bottom line}

There are conflicting findings regarding the efficacy of off-pump CABG on decreasing the risk of CS-AKI, but consistent findings regarding lack of efficacy in preventing moderate to severe CS-AKI.

\section{Leukocyte Filtration}

\section{Rationale}

There is evidence from both animal and human studies that neutrophils and other leukocytes accumulate in the kidneys in the setting of AKI and play an important role in mediating tubular injury. ${ }^{58}$ The application of leukocyte filters and cytokine filtration techniques has therefore been researched in several studies of CS-AKI prevention.

\section{Findings}

A recent meta-analysis of 6 RCTs that enrolled a total of 374 patients concluded that leukocyte filters did indeed protect against CS-AKI (odds ratio, 0.18; 95\% confidence interval, 0.05-0.64). ${ }^{6}$ However, caution is necessary in interpreting these results, because the sample sizes of the studies were relatively small, and the definitions used for CS-AKI varied from study to study. 


\begin{tabular}{|c|c|c|c|c|c|c|c|}
\hline Trial & Multicenter & $\begin{array}{l}\text { Double } \\
\text { Blinded }\end{array}$ & No. of Patients & $\begin{array}{l}\text { Cardiac } \\
\text { Surgery Type }\end{array}$ & Intervention & AKI Definition & Primary Outcome \\
\hline $\begin{array}{l}\text { Lamy et al, }, 5 \\
2012, \text { Int }\end{array}$ & Yes & No & 4752 & CABG & Off-pump surgery & $\begin{array}{l}\text { RIFLE stages } R, \\
I \text { and } F \text {, and RRT }\end{array}$ & $\begin{array}{l}\text { Off-pump CABG did not decrease } \\
\text { the incidence of RRT (HR, } 1.04 ; \\
95 \% \mathrm{Cl}, 0.61-1.76) \text {. Off-pump } \\
\text { CABG did decrease the incidence } \\
\text { of RIFLE stage R (HR, } 0.87 ; 95 \% \mathrm{Cl} \text {, } \\
0.76-0.98 \text { ) }\end{array}$ \\
\hline $\begin{array}{l}\text { Diegeler et al, } \\
2013 \text {, Germany }\end{array}$ & Yes & No & 2539 & CABG & Off-pump surgery & RRT & $\begin{array}{l}\text { Off-pump CABG did not decrease } \\
\text { the incidence of RRT (HR, 0.80; } \\
95 \% \mathrm{Cl}, 0.49-1.29)\end{array}$ \\
\hline $\begin{array}{l}\text { Lemma et al, }{ }^{99} \\
2012 \text {, Italy }\end{array}$ & Yes & No & 693 & CABG & Off-pump surgery & RIFLE stage I & $\begin{array}{l}\text { Off-pump CABG did not decrease } \\
\text { the incidence of CS-AKI }(P=.15) \\
\end{array}$ \\
\hline $\begin{array}{l}\text { Cogliati et al, }{ }^{102} \\
2007 \text {, Italy }\end{array}$ & No & Yes & 193 & $\begin{array}{l}\text { CABG, valve, } \\
\text { combined }\end{array}$ & Fenoldopam & $\begin{array}{l}\text { Postoperative } \\
\mathrm{SCr}>2 \mathrm{mg} / \mathrm{dL} \text { or } \\
\geq 0.7 \mathrm{mg} / \mathrm{dL} \mathrm{SCr} \\
\text { increase }\end{array}$ & $\begin{array}{l}\text { Fenoldopam decreased the } \\
\text { incidence of CS-AKI }(P=.004)\end{array}$ \\
\hline $\begin{array}{r}\text { Bove et al, }{ }^{65} \\
2014, \text { Italy }\end{array}$ & Yes & Yes & 667 & $\begin{array}{c}\text { CABG, valve, } \\
\text { combined }\end{array}$ & Fenoldopam & RRT & $\begin{array}{l}\text { Fenoldopam did not decrease the } \\
\text { incidence of RRT }(P=.47)\end{array}$ \\
\hline
\end{tabular}




\begin{tabular}{|c|c|c|c|c|c|c|c|}
\hline \multicolumn{8}{|l|}{$\begin{array}{l}\text { Table } 3 \\
\text { (continued) }\end{array}$} \\
\hline Trial & Multicenter & $\begin{array}{l}\text { Double } \\
\text { Blinded } \\
\end{array}$ & No. of Patients & $\begin{array}{l}\text { Cardiac } \\
\text { Surgery Type } \\
\end{array}$ & Intervention & AKI Definition & Primary Outcome \\
\hline $\begin{array}{l}\text { Lahtinen et al, } \\
\text { 2011, Finland }\end{array}$ & No & Yes & 200 & $\begin{array}{l}\text { CABG, valve, } \\
\text { combined }\end{array}$ & Levosimendan & $\begin{array}{l}\geq 50 \% \mathrm{SCr} \text { increase } \\
\text { or RRT }\end{array}$ & $\begin{array}{l}\text { Levosimendan did not decrease the } \\
\text { incidence of CS-AKI (RR, 1.02; 95\% } \\
\text { CI, 0.37-2.84) }\end{array}$ \\
\hline $\begin{array}{l}\text { Landoni et al, } \\
2017 \text {, Int }\end{array}$ & Yes & Yes & 506 & $\begin{array}{l}\text { CABG, valve, } \\
\text { combined }\end{array}$ & Levosimendan & $\begin{array}{l}\text { RIFLE stages } R_{r} \\
\text { I, F and RRT }\end{array}$ & $\begin{array}{l}\text { Levosimendan did not decrease the } \\
\text { incidence of any RIFLE stage or } \\
\text { RRT }(P=.18 ; .98 ; .49 \text {, and } .27 \\
\text { respectively) }\end{array}$ \\
\hline $\begin{array}{l}\text { Mehta et al, }{ }^{69} \\
\text { 2017, Int }\end{array}$ & Yes & Yes & 882 & $\begin{array}{c}\text { CABG, valve, } \\
\text { combined }\end{array}$ & Levosimendan & RRT & $\begin{array}{l}\text { Levosimendan did not decrease the } \\
\text { incidence of RRT (RR, } 0.54 ; 95 \% \mathrm{Cl} \text {, } \\
0.24-1.24 \text { ) }\end{array}$ \\
\hline $\begin{array}{l}\text { Lei \& Berra, }{ }^{72} \\
\text { 2018, China }\end{array}$ & No & Yes & 244 & Multiple valve & NO & KDIGO stage 1 & $\begin{array}{l}\text { NO decreased the incidence of } \\
\text { CS-AKI (RR, 0.78; } 95 \% \mathrm{Cl} \text {, } \\
0 \cdot 62-0.97)\end{array}$ \\
\hline
\end{tabular}

Abbreviations: ANP, atrial natriuretic peptide; $\mathrm{BNP}$, brain natriuretic peptide; $\mathrm{CABG}$, coronary artery bypass grafting; $\mathrm{Cl}$, confidence interval; $\mathrm{HR}$, hazard ratio; Int international; KDIGO, Kidney Disease Improving Global Outcome; NO, nitric oxide; RIFLE, Risk, Injury, Failure, Loss, and End-stage renal disease; RR, relative risk; $\mathrm{SCr}$, serum creatinine. 


\section{Bottom line}

Additional research is needed to evaluate the efficacy of leukocyte filters for the prevention of CS-AKI.

\section{Vasodilators and Inotropes}

\section{Rationale}

Renal vasodilators, including natriuretic peptide, fenoldopam, and levosimendan, have been found to increase renal blood flow in a rat model. ${ }^{59}$ Natriuretic peptide consists of atrial natriuretic peptide, brain natriuretic peptide, and C-type natriuretic peptide. Atrial natriuretic peptide and brain natriuretic peptide, administered as human analogues, may have renoprotective properties, including anti-inflammatory effects and the reduction of renal ischemia-reperfusion injury via upregulation of intrarenal angiotensin II. ${ }^{60}$ Fenoldopam, a dopamine 1 receptor partial agonist, may reverse renal hypoperfusion and have anti-inflammatory effects in humans. ${ }^{61}$ Levosimendan is an adenosine triphosphate-sensitive potassium channel opener that could improve renal perfusion in the vasoplegic state after cardiac surgery by inducing mesangial cell relaxation. In animal models, administration of levosimendan before injury significantly improved renal tubular ischemia-reperfusion injury. ${ }^{59}$

\section{Findings}

Two meta-analyses assessed pooled data from 9 small RCTs of intraoperative administration of natriuretic peptides for prevention of CS-AKI. These trials, which enrolled nearly 1000 patients, found a significantly decreased incidence of postoperative $\mathrm{AKI}$ in patients who received natriuretic peptides. ${ }^{51,62,63} \mathrm{~A}$ meta-analysis of RCTs performed in patients undergoing cardiac surgery and other major surgery indicated that fenoldopam led to a lower risk of AKI, but not RRT or death. ${ }^{64}$ However, these studies also had small sample sizes and were of variable quality. Recently, a large multicenter, double-blind, RCT failed to show any renoprotective effects or survival benefits of fenoldopam infusion in patients undergoing cardiac surgery. Fenoldopam was even related to increased rates of hypotension. ${ }^{65}$ Meta-analyses of small sized RCTs concluded that levosimendan resulted in a significant decrease in the incidence of AKI after cardiac surgical procedures. ${ }^{63,66,67}$ However, the 2 largest RCTs conducted to date, failed to report any beneficial effects of levosimendan in preventing severe AKI (defined as need for RRT) in patients undergoing cardiac surgery. ${ }^{68,69}$

\section{Bottom line}

Natriuretic peptides seem to have some protective effects on CS-AKI, but large RCTs are still needed to confirm this effect. There is no definite evidence that fenoldopam nor levosimendan protects against postoperative AKI.

\section{Nitric Oxide}

\section{Rationale}

During hemolysis in cardiac surgery, $\mathrm{Hb}$ is released into the circulation in the form of oxyhemoglobin (Oxy- $\mathrm{Hb})$. Nitric oxide (NO) is a potent vasodilator, which relaxes vascular smooth muscle, and $\mathrm{NO}$ depletion by plasma Oxy-Hb produces vasoconstriction, impairs tissue perfusion, and causes inflammation in animal models. ${ }^{70}$ Consequently, plasma Oxy-Hb facilitates development of AKI by intrarenal oxidative reactions. ${ }^{71}$ The administration of exogenous $\mathrm{NO}$ gas oxidizes plasma $\mathrm{Oxy}-\mathrm{Hb}$ to methemoglobin and might thus prevent CS-AKI. 


\section{Findings}

In a randomized clinical trial in China of 217 adults with rheumatic valve disease undergoing elective, multiple valve replacement surgery, administration of 80 parts per million of NO during and after prolonged CPB reduced the incidence of CS-AKI and improved renal function at a follow-up of 1 year after surgery. ${ }^{72}$

\section{Bottom line}

$\mathrm{NO}$ intraoperatively seems to decrease the incidence of $\mathrm{AKI}$ in a Chinese population undergoing cardiac surgery. More trials are necessary to establish its use in Caucasians and those with calcific vessel or valve disease.

\section{POSTOPERATIVE MEASURES}

A variety of postoperative interventions have been studied for prevention of CS-AKI, including a KDIGO-based bundle of care, several resuscitation strategies, restrictive packed red blood cell (pRBC) transfusions, and strict glycemic control. Major RCTs conducted in this area that included 100 or more patients are summarized in Table 4.

\section{Kidney Disease: Improving Global Outcomes-Based Bundle of Care}

\section{Rationale}

Because of the multifactorial nature of CS-AKI, it is likely that a combination of interventions, rather than a single intervention, is needed to result in meaningful reductions in the incidence of CS-AKI.

\section{Findings}

The PrevAKI RCT was a single-center trial that investigated the use of KDIGO guidelines in the prevention of postoperative AKI in high-risk patients who were identified using a urinary (TIMP-2)/(IGFBP7) ratio of greater than $0.3 .{ }^{73}$ The investigators assessed the effect of a KDIGO bundle of care, consisting of optimization of volume status and hemodynamics, avoidance of nephrotoxic drugs, and prevention of hyperglycemia, among patients undergoing cardiac surgery. Implementation of the KDIGO bundle of care decreased the incidence and severity of AKI after cardiac surgery in these high-risk patients. ${ }^{73}$

\section{Bottom line}

The results from this single-center trial are promising. However, an adequately powered multicenter trial is needed to confirm whether implementation of a KDIGObased bundle of care is effective in reducing CS-AKI.

\section{Fluid Management Strategies}

\section{Rationale}

Fluid management in the perioperative setting is complex and controversial. Fluid overload and hypovolemia are each associated with worse outcomes, including $\mathrm{AKI}$, among patients undergoing cardiac surgery.

\section{Findings}

A multicenter, double-blind, double-crossover RCT known as the SPLIT Trial assessed the use of a buffered crystalloid solution compared with saline in 2278 patients who were admitted to the intensive care unit and who required fluid therapy (50\% of these were cardiac surgery patients). They found similar rates of postoperative $\mathrm{AKI}$ in both fluid management strategies. ${ }^{74}$ These results require additional investigation, however, because saline resuscitation in other settings, including critical 


\begin{tabular}{|c|c|c|c|c|c|c|c|}
\hline Trial & Multicenter & $\begin{array}{l}\text { Double } \\
\text { Blinded }\end{array}$ & $\begin{array}{l}\text { No. of } \\
\text { Patients }\end{array}$ & $\begin{array}{l}\text { Cardiac } \\
\text { Surgery } \\
\text { Type } \\
\end{array}$ & Intervention & AKI Definition & Primary Outcome \\
\hline $\begin{array}{l}\text { Meersch et al, }{ }^{73} \\
2017, \text { Germany }\end{array}$ & No & No & 276 & $\begin{array}{l}\text { CABG, valve, } \\
\text { combined }\end{array}$ & $\begin{array}{l}\text { KDIGO-based } \\
\text { approach }\end{array}$ & KDIGO stage $1-3$ & $\begin{array}{l}\text { The KDIGO-based approach decreased } \\
\text { the incidence of CS-AKI (OR, } \\
0.48 ; 95 \% \mathrm{Cl}, 0.29-0.80)\end{array}$ \\
\hline $\begin{array}{l}\text { Young et al, }{ }^{74} \\
2015, \text { Australia }\end{array}$ & Yes & Yes & 2278 & NS & $\begin{array}{l}\text { Crystalloid vs saline } \\
\text { resuscitation }\end{array}$ & RIFLE stage $R, I, F$ & $\begin{array}{l}\text { Crystalloids vs saline did not decrease } \\
\text { the incidence of AKI (RR, 1.04; } \\
95 \% \mathrm{Cl}, 0.80-1.36)\end{array}$ \\
\hline $\begin{array}{l}\text { Hajjar et al, }{ }^{104} \\
\text { 2010, Brazil }\end{array}$ & Yes & No & 502 & $\begin{array}{l}\text { CABG, valve, } \\
\text { combined }\end{array}$ & $\begin{array}{l}\text { Restrictive ( } \mathrm{Ht} \geq 24 \%) \\
\text { threshold for pRBC } \\
\text { transfusion }\end{array}$ & RRT & $\begin{array}{l}\text { Restrictive vs liberal threshold for } \mathrm{pRBC} \\
\text { transfusion did not decrease the } \\
\text { incidence of RRT }(P=.99)\end{array}$ \\
\hline $\begin{array}{l}\text { Murphy et al, }{ }^{105} \\
\text { 2015, UK }\end{array}$ & Yes & No & 2007 & $\begin{array}{l}\text { CABG, valve, } \\
\text { combined }\end{array}$ & $\begin{array}{l}\text { Restrictive }(\mathrm{Hb}<7.5 \mathrm{~g} / \mathrm{dL}) \\
\text { threshold for } \mathrm{pRBC} \\
\text { transfusion }\end{array}$ & AKIN stages $1-3$ & $\begin{array}{l}\text { Restrictive vs liberal threshold for pRBC } \\
\text { transfusion did not decrease the } \\
\text { incidence of CS-AKI }(P>.05)\end{array}$ \\
\hline $\begin{array}{l}\text { Mazer et al, } \\
2017, \text { Int }\end{array}$ & Yes & No & 5243 & $\begin{array}{l}\text { CABG, valve, } \\
\text { combined }\end{array}$ & $\begin{array}{l}\text { Restrictive }(\mathrm{Hb}<7.5 \mathrm{~g} / \mathrm{dL}) \\
\text { threshold for } \mathrm{pRBC} \\
\text { transfusion }\end{array}$ & RRT & $\begin{array}{l}\text { Restrictive vs liberal threshold for pRBC } \\
\text { transfusion did not decrease the } \\
\text { incidence of RRT (HR, } 0.84 ; 95 \% \mathrm{Cl} \text {, } \\
0.60-1.19)\end{array}$ \\
\hline $\begin{array}{l}\text { Steiner et al, } \\
\text { 2015, USA }\end{array}$ & Yes & No & 1098 & $\begin{array}{l}\text { CABG, valve, } \\
\text { combined }\end{array}$ & $\begin{array}{l}\text { Fresh }(\leq 10 \mathrm{~d}) \text { vs old } \\
\operatorname{pRBC}(\geq 21 \mathrm{~d})\end{array}$ & SCr change & $\begin{array}{l}\text { Fresh vs old pRBC did not decrease the } \\
\text { incidence of CS-AKI }(P=.72)\end{array}$ \\
\hline $\begin{array}{c}\text { Desai et al, } \\
\text { 2012, USA }\end{array}$ & No & No & 189 & CABG & $\begin{array}{l}\text { Tight }(90-120 \mathrm{mg} / \mathrm{dL}) \\
\text { vs liberal }(121-180 \mathrm{mg} / \mathrm{dL}) \\
\text { glucose ranges }\end{array}$ & RIFLE stage $\mathrm{F}$ & $\begin{array}{l}\text { Tight vs liberal glucose control did not } \\
\text { decrease the incidence of CS-AKI } \\
\text { (absolute difference } 2.2 \% ; 95 \% \mathrm{Cl} \text {, } \\
-5 \% \text { to } 8 \% \text { ) }\end{array}$ \\
\hline $\begin{array}{l}\text { Umpierrez et al, }{ }^{87} \\
\text { 2015, USA }\end{array}$ & Yes & No & 302 & CABG, valve & $\begin{array}{l}\text { Tight }(100-140 \mathrm{mg} / \mathrm{dL}) \\
\text { vs liberal }(141-180 \mathrm{mg} / \mathrm{dL}) \\
\text { glucose ranges }\end{array}$ & $\geq 50 \% \mathrm{SCr}$ increase & $\begin{array}{l}\text { Tight vs liberal glucose control did not } \\
\text { decrease the incidence of } \\
\text { CS-AKI }(P=.08) \text {. }\end{array}$ \\
\hline
\end{tabular}

Abbreviations: $\mathrm{CABG}$, coronary artery bypass grafting; $\mathrm{Cl}$, confidence interval; $\mathrm{HR}$, hazard ratio; $\mathrm{Ht}$, hematocrit; Int, international; KDIGO, Kidney Disease Improving Global Outcome; NS, not specified; OR, odds ratio; RIFLE, Risk, Injury, Failure, Loss, and End-stage renal disease; RR, relative risk; SCr, serum creatinine. 
illness, has been shown to result in higher rates of AKI as compared with balanced solutions. ${ }^{75}$

Noteworthy, concerns have been raised regarding administration of higher molecular weight hydroxyethyl starches as part of fluid resuscitation in various settings, including cardiac surgery, because this approach seems to be associated with a higher incidence of AKI requiring RRT. ${ }^{76,77}$

\section{Bottom line}

Additional studies are needed to investigate the effects of resuscitation using normal saline versus balanced solutions (eg, Ringer's lactate) on the incidence of CS-AKI. Hydroxyethyl starches are contradicted in cardiac surgery.

\section{Packed Red Blood Cell Transfusions}

\section{Rationale}

Anemia and transfusion of pRBCs are each associated with an increased risk of CS$\mathrm{AKI},{ }^{78,79}$ but direct causal relationships in this setting cannot be determined from observational studies owing to confounding by severity of illness. Thus, optimal transfusion thresholds can only be determined from RCTs. Additionally, a large retrospective cohort study ( $n=2872$ ) found that transfusion of older pRBCs is associated with worse outcomes postoperatively following cardiac surgery, including in-hospital, renal failure and sepsis. ${ }^{80}$

\section{Findings}

The TRICs-III study is a recently published RCT that assessed the effects of a restrictive versus liberal threshold for transfusion of pRBCs in 5243 adults undergoing cardiac surgery. The restrictive transfusion group received $\mathrm{pRBCs}$ if their $\mathrm{Hb}$ concentration decreased to less than $7.5 \mathrm{~g} / \mathrm{dL}$, whereas the liberal transfusion group received pRBCs if their $\mathrm{Hb}$ concentration decreased to less than $9.5 \mathrm{~g} / \mathrm{dL}$. The investigators found that the incidence of AKI requiring RRT was similar in both groups. ${ }^{81} \mathrm{~A}$ recent meta-analysis found similar results. ${ }^{82}$ Of note, only 1 RCT (the RECESS trial) investigated the effects of storage time of pRBCs on outcomes after cardiac surgery. ${ }^{83}$ This trial, which included 1098 patients, found that transfusion of pRBCs stored for 10 or fewer days was not superior to transfusion of pRBCs stored for 21 or more days with respect to severe organ dysfunction. ${ }^{83}$

\section{Bottom line}

The use of a restrictive versus liberal threshold for perioperative $\mathrm{pRBC}$ transfusion does not affect the incidence of CS-AKI. Additionally, the storage duration of pRBCs does not seem to affect the incidence of CS-AKI.

\section{Glycemic Control}

\section{Rationale}

Perioperative hyperglycemia is associated with increased mortality, surgical complications, and $\mathrm{AKI} .{ }^{84}$ Mechanisms by which hyperglycemia could predispose patients to a greater susceptibility to AKI are not entirely clear; however, hyperglycemia is known to induce oxidative stress and also to inhibit sodium-glucose co-transporters in the renal proximal tubules. ${ }^{85}$

\section{Findings}

Two RCTs ( $\mathrm{N}=189$ and $\mathrm{N}=302)$ assessed the effect of tight $(100-140 \mathrm{mg} / \mathrm{dL})$ versus liberal (141-180 $\mathrm{mg} / \mathrm{dL})$ glycemic control. These studies found no difference in the incidence of CS-AKI. ${ }^{86,87}$ 


\section{Bottom line}

Liberal glycemic control has the same effects on CS-AKI as tight glycemic control. Consequently, this has prompted the Society for Thoracic Surgeons to issue guidelines for blood glucose management after cardiac surgery, recommending targeting blood glucose levels of less than $180 \mathrm{mg} / \mathrm{dL}^{88}$

\section{DISCUSSION}

CS-AKI remains a complex and challenging problem. Numerous trials of various preoperative, intraoperative, and postoperative preventive measures have been attempted, yet the majority of RCTs were negative. Preliminary data suggest that a KDIGO-based bundle of care, which includes optimization of volume status and hemodynamics, avoidance of nephrotoxic drugs, and prevention of hyperglycemia, might help to decrease the incidence of CS-AKI. ${ }^{3,73}$ These strategies are low-cost and relatively easy to implement in clinical practice. Although these strategies are promising, larger studies are still needed to confirm these findings.

The use of anti-inflammatory interventions such as steroids, RIPC, statins, NAC, and urinary alkalization seems to be ineffective in preventing CS-AKI in the general cardiac surgery population. Post hoc analyses, however, have shown that certain subgroups of patients may benefit from some of these interventions, for example, corticosteroids. ${ }^{21}$ Of all intraoperative measures that have been investigated, none except leukocyte filtration and inhaled NO has proven to be of benefit in protecting against CS-AKI. Yet, the positive findings related to these 2 interventions are based on RCTs that had small sample sizes; thus, additional research is needed to confirm these findings.

One important reason why the majority of RCTs may have been negative is because they assessed interventions aimed at a general cardiac surgical population. Future RCTs should include more precise phenotyping of patients to determine which patients are at the greatest risk of developing AKI, and as such would likely benefit most from the intervention, rather than a one-size-fits-all approach. Phenotyping could be performed through the use of clinical characteristics (eg, preoperative estimated glomerular filtration rate, diabetes mellitus), blood and urine biomarkers (eg, urinary [TIMP-2]/[IGFBP7] ratio, urinary neutrophil gelatinase-associated lipocalin, or plasma fibroblast growth factor-23), ${ }^{10,13,89}$ immune characteristics, ${ }^{90}$ or (epi)genetic markers. ${ }^{91}$

\section{SUMMARY}

Thousands of patients have been enrolled in clinical trials assessing various therapeutic strategies for prevention of CS-AKI, and the vast majority of these studies have been negative. More comprehensive phenotyping of patients may yield higher success rates in future trials, and could be accomplished through a variety of approaches. Finally, implementation of a KDIGO bundle of care the and administration of inhaled NO intraoperatively represent promising therapeutic strategies. However, the efficacy of these strategies in preventing CS-AKI requires confirmation in larger, multicenter trials before they can be recommended for widespread implementation.

\section{REFERENCES}

1. Roger VL, Go AS, Lloyd-Jones DM, et al. Heart disease and stroke statistics2011 update: a report from the American Heart Association. Circulation 2011; 123(4):e18-209. 
2. D'Agostino RS, Jacobs JP, Badhwar V, et al. The Society of Thoracic Surgeons adult cardiac surgery database: 2019 update on outcomes and quality. Ann Thorac Surg 2019;107(1):24-32.

3. Wang Y, Bellomo R. Cardiac surgery-associated acute kidney injury: risk factors, pathophysiology and treatment. Nat Rev Nephrol 2017;13(11):697-711.

4. Chertow GM, Burdick E, Honour M, et al. Acute kidney injury, mortality, length of stay, and costs in hospitalized patients. J Am Soc Nephrol 2005;16(11): 3365-70.

5. Rosner MH, Okusa MD. Acute kidney injury associated with cardiac surgery. Clin J Am Soc Nephrol 2006;1(1):19-32.

6. Scrascia G, Guida P, Rotunno C, et al. Anti-inflammatory strategies to reduce acute kidney injury in cardiac surgery patients: a meta-analysis of randomized controlled trials. Artif Organs 2014;38(2):101-12.

7. Mariscalco G, Lorusso R, Dominici C, et al. Acute kidney injury: a relevant complication after cardiac surgery. Ann Thorac Surg 2011;92(4):1539-47.

8. Ranucci M, Pavesi M, Mazza E, et al. Risk factors for renal dysfunction after coronary surgery: the role of cardiopulmonary bypass technique. Perfusion 1994; $9(5): 319-26$.

9. Wijeysundera DN, Karkouti K, Dupuis JY, et al. Derivation and validation of a simplified predictive index for renal replacement therapy after cardiac surgery. JAMA 2007;297(16):1801-9.

10. Parikh CR, Coca SG, Thiessen-Philbrook H, et al. Postoperative biomarkers predict acute kidney injury and poor outcomes after adult cardiac surgery. J Am Soc Nephrol 2011;22(9):1748-57.

11. Asimakopoulos G. Systemic inflammation and cardiac surgery: an update. Perfusion 2001;16(5):353-60.

12. Okusa MD. The inflammatory cascade in acute ischemic renal failure. Nephron 2002;90(2):133-8.

13. Leaf DE, Rajapurkar M, Lele SS, et al. Increased plasma catalytic iron in patients may mediate acute kidney injury and death following cardiac surgery. Kidney Int 2015;87(5):1046-54.

14. Paparella D, Yau TM, Young E. Cardiopulmonary bypass induced inflammation: pathophysiology and treatment. An update. Eur J Cardiothorac Surg 2002; 21(2):232-44.

15. Moat NE, Shore DF, Evans TW. Organ dysfunction and cardiopulmonary bypass: the role of complement and complement regulatory proteins. Eur J Cardiothorac Surg 1993;7(11):563-73.

16. Wan S, LeClerc JL, Vincent JL. Inflammatory response to cardiopulmonary bypass: mechanisms involved and possible therapeutic strategies. Chest 1997;112(3):676-92.

17. Dieleman JM, van Paassen J, van Dijk D, et al. Prophylactic corticosteroids for cardiopulmonary bypass in adults. Cochrane Database Syst Rev 2011;(5):CD005566.

18. Dieleman JM, Nierich AP, Rosseel PM, et al. Intraoperative high-dose dexamethasone for cardiac surgery: a randomized controlled trial. JAMA 2012;308(17): $1761-7$.

19. Whitlock RP, Devereaux PJ, Teoh KH, et al. Methylprednisolone in patients undergoing cardiopulmonary bypass (SIRS): a randomised, double-blind, placebo-controlled trial. Lancet 2015;386(10000):1243-53.

20. Dvirnik N, Belley-Cote EP, Hanif H, et al. Steroids in cardiac surgery: a systematic review and meta-analysis. Br J Anaesth 2018;120(4):657-67. 
21. Jacob KA, Leaf DE, Dieleman JM, et al. Intraoperative high-dose dexamethasone and severe AKI after cardiac surgery. J Am Soc Nephrol 2015;26(12): 2947-51.

22. Leaf DE, Waikar SS. End points for clinical trials in acute kidney injury. Am J Kidney Dis 2017;69(1):108-16.

23. Choi YS, Shim JK, Kim JC, et al. Effect of remote ischemic preconditioning on renal dysfunction after complex valvular heart surgery: a randomized controlled trial. J Thorac Cardiovasc Surg 2011;142(1):148-54.

24. Gassanov N, Nia AM, Caglayan E, et al. Remote ischemic preconditioning and renoprotection: from myth to a novel therapeutic option? J Am Soc Nephrol 2014;25(2):216-24.

25. Kharbanda RK, Nielsen TT, Redington AN. Translation of remote ischaemic preconditioning into clinical practice. Lancet 2009;374(9700):1557-65.

26. Hausenloy DJ, Candilio L, Evans R, et al. Remote ischemic preconditioning and outcomes of cardiac surgery. N Engl J Med 2015;373(15):1408-17.

27. Meybohm $\mathrm{P}$, Bein $\mathrm{B}$, Brosteanu $\mathrm{O}$, et al. A multicenter trial of remote ischemic preconditioning for heart surgery. N Engl J Med 2015;373(15):1397-407.

28. Zimmerman RF, Ezeanuna PU, Kane JC, et al. Ischemic preconditioning at a remote site prevents acute kidney injury in patients following cardiac surgery. Kidney Int 2011;80(8):861-7.

29. Menting TP, Wever KE, Ozdemir-van Brunschot DM, et al. Ischaemic preconditioning for the reduction of renal ischaemia reperfusion injury. Cochrane Database Syst Rev 2017;(3):CD010777.

30. Pierce B, Bole I, Patel V, et al. Clinical outcomes of remote ischemic preconditioning prior to cardiac surgery: a meta-analysis of randomized controlled trials. J Am Heart Assoc 2017;6(2) [pii:e004666].

31. Baliga R, Ueda N, Walker PD, et al. Oxidant mechanisms in toxic acute renal failure. Am J Kidney Dis 1997;29(3):465-77.

32. Lee JH, Jo YH, Kim K, et al. Effect of N-acetylcysteine (NAC) on acute lung injury and acute kidney injury in hemorrhagic shock. Resuscitation 2013;84(1): $121-7$.

33. Campos R, Shimizu MH, Volpini RA, et al. N-acetylcysteine prevents pulmonary edema and acute kidney injury in rats with sepsis submitted to mechanical ventilation. Am J Physiol Lung Cell Mol Physiol 2012;302(7):L640-50.

34. Tepel M, van der Giet M, Schwarzfeld C, et al. Prevention of radiographiccontrast-agent-induced reductions in renal function by acetylcysteine. N Engl J Med 2000;343(3):180-4.

35. Weisbord SD, Gallagher M, Jneid H, et al. Outcomes after angiography with sodium bicarbonate and acetylcysteine. N Engl J Med 2018;378(7):603-14.

36. Burns KE, Chu MW, Novick RJ, et al. Perioperative N-acetylcysteine to prevent renal dysfunction in high-risk patients undergoing CABG surgery: a randomized controlled trial. JAMA 2005;294(3):342-50.

37. Adabag AS, Ishani A, Bloomfield HE, et al. Efficacy of N-acetylcysteine in preventing renal injury after heart surgery: a systematic review of randomized trials. Eur Heart J 2009;30(15):1910-7.

38. Mei M, Zhao HW, Pan QG, et al. Efficacy of N-acetylcysteine in preventing acute kidney injury after cardiac surgery: a meta-analysis study. J Invest Surg 2018; 31(1):14-23.

39. Billings FT, Hendricks PA, Schildcrout JS, et al. High-Dose perioperative atorvastatin and acute kidney injury following cardiac surgery: a randomized clinical trial. JAMA 2016;315(9):877-88. 
40. Park JH, Shim JK, Song JW, et al. Effect of atorvastatin on the incidence of acute kidney injury following valvular heart surgery: a randomized, placebo-controlled trial. Intensive Care Med 2016;42(9):1398-407.

41. Zheng Z, Jayaram R, Jiang $L$, et al. Perioperative rosuvastatin in cardiac surgery. N Engl J Med 2016;374(18):1744-53.

42. Kuhn EW, Slottosch I, Wahlers T, et al. Preoperative statin therapy for patients undergoing cardiac surgery. Cochrane Database Syst Rev 2015;(8):CD008493.

43. Liakopoulos OJ, Choi YH, Haldenwang PL, et al. Impact of preoperative statin therapy on adverse postoperative outcomes in patients undergoing cardiac surgery: a meta-analysis of over 30,000 patients. Eur Heart J 2008;29(12):1548-59.

44. Yuan X, Du J, Liu Q, et al. Defining the role of perioperative statin treatment in patients after cardiac surgery: a meta-analysis and systematic review of 20 randomized controlled trials. Int J Cardiol 2017;228:958-66.

45. Putzu A, Capelli B, Belletti A, et al. Perioperative statin therapy in cardiac surgery: a meta-analysis of randomized controlled trials. Crit Care 2016;20(1):395.

46. Caulfield JL, Singh SP, Wishnok JS, et al. Bicarbonate inhibits N-nitrosation in oxygenated nitric oxide solutions. J Biol Chem 1996;271(42):25859-63.

47. Atkins JL. Effect of sodium bicarbonate preloading on ischemic renal failure. Nephron 1986;44(1):70-4.

48. Haase M, Haase-Fielitz A, Bellomo R, et al. Sodium bicarbonate to prevent increases in serum creatinine after cardiac surgery: a pilot double-blind, randomized controlled trial. Crit Care Med 2009;37(1):39-47.

49. Haase M, Haase-Fielitz A, Plass M, et al. Prophylactic perioperative sodium bicarbonate to prevent acute kidney injury following open heart surgery: a multicenter double-blinded randomized controlled trial. PLoS Med 2013;10(4): e1001426.

50. Bailey M, McGuinness S, Haase M, et al. Sodium bicarbonate and renal function after cardiac surgery: a prospectively planned individual patient meta-analysis. Anesthesiology 2015;122(2):294-306.

51. Kim JH, Kim HJ, Kim JY, et al. Meta-analysis of sodium bicarbonate therapy for prevention of cardiac surgery-associated acute kidney injury. J Cardiothorac Vasc Anesth 2015;29(5):1248-56.

52. Tie HT, Luo MZ, Luo MJ, et al. Sodium bicarbonate in the prevention of cardiac surgery-associated acute kidney injury: a systematic review and meta-analysis. Crit Care 2014;18(5):517.

53. Leaf DE, Swinkels DW. Catalytic iron and acute kidney injury. Am J Physiol Renal Physiol 2016;311(5):F871-6.

54. Lamy A, Devereaux PJ, Prabhakaran D, et al. Off-pump or on-pump coronaryartery bypass grafting at 30 days. N Engl J Med 2012;366(16):1489-97.

55. Shroyer AL, Grover FL, Hattler B, et al. On-pump versus off-pump coronary-artery bypass surgery. N Engl J Med 2009;361(19):1827-37.

56. Diegeler A, Borgermann J, Kappert U, et al. Off-pump versus on-pump coronary-artery bypass grafting in elderly patients. N Engl J Med 2013;368(13): 1189-98.

57. Garg AX, Devereaux PJ, Yusuf S, et al. Kidney function after off-pump or onpump coronary artery bypass graft surgery: a randomized clinical trial. JAMA 2014;311(21):2191-8.

58. Bolisetty S, Agarwal A. Neutrophils in acute kidney injury: not neutral any more. Kidney Int 2009;75(7):674-6. 
59. Yakut N, Yasa H, Bahriye Lafci B, et al. The influence of levosimendan and iloprost on renal ischemia-reperfusion: an experimental study. Interact Cardiovasc Thorac Surg 2008;7(2):235-9.

60. Mitaka C, Si MK, Tulafu M, et al. Effects of atrial natriuretic peptide on inter-organ crosstalk among the kidney, lung, and heart in a rat model of renal ischemiareperfusion injury. Intensive Care Med Exp 2014;2(1):28.

61. Gillies MA, Kakar V, Parker RJ, et al. Fenoldopam to prevent acute kidney injury after major surgery-a systematic review and meta-analysis. Crit Care 2015; 19:449.

62. Nigwekar SU, Navaneethan SD, Parikh CR, et al. Atrial natriuretic peptide for preventing and treating acute kidney injury. Cochrane Database Syst Rev 2009; (4):CD006028.

63. Chen X, Huang T, Cao X, et al. Comparative efficacy of drugs for preventing acute kidney injury after cardiac surgery: a network meta-analysis. Am J Cardiovasc Drugs 2018;18(1):49-58.

64. Zangrillo A, Biondi-Zoccai GG, Frati E, et al. Fenoldopam and acute renal failure in cardiac surgery: a meta-analysis of randomized placebo-controlled trials. J Cardiothorac Vasc Anesth 2012;26(3):407-13.

65. Bove T, Zangrillo A, Guarracino F, et al. Effect of fenoldopam on use of renal replacement therapy among patients with acute kidney injury after cardiac surgery: a randomized clinical trial. JAMA 2014;312(21):2244-53.

66. Zhou C, Gong J, Chen D, et al. Levosimendan for prevention of acute kidney injury after cardiac surgery: a meta-analysis of randomized controlled trials. Am J Kidney Dis 2016;67(3):408-16.

67. Niu ZZ, Wu SM, Sun WY, et al. Perioperative levosimendan therapy is associated with a lower incidence of acute kidney injury after cardiac surgery: a meta-analysis. J Cardiovasc Pharmacol 2014;63(2):107-12.

68. Landoni G, Lomivorotov VV, Alvaro G, et al. Levosimendan for hemodynamic support after cardiac surgery. N Engl J Med 2017;376(21):2021-31.

69. Mehta RH, Leimberger JD, van Diepen S, et al. Levosimendan in patients with left ventricular dysfunction undergoing cardiac surgery. N Engl J Med 2017; 376(21):2032-42.

70. Minneci PC, Deans KJ, Zhi H, et al. Hemolysis-associated endothelial dysfunction mediated by accelerated NO inactivation by decompartmentalized oxyhemoglobin. J Clin Invest 2005;115(12):3409-17.

71. Deuel JW, Schaer CA, Boretti FS, et al. Hemoglobinuria-related acute kidney injury is driven by intrarenal oxidative reactions triggering a heme toxicity response. Cell Death Dis 2016;7:e2064.

72. Lei C, Berra L. Nitric oxide decreases acute kidney injury and stage 3 chronic kidney disease after cardiac surgery. Am J Respir Crit Care Med 2018; 198(10):1279-87.

73. Meersch M, Schmidt C, Hoffmeier A, et al. Prevention of cardiac surgeryassociated AKI by implementing the KDIGO guidelines in high risk patients identified by biomarkers: the PrevAKI randomized controlled trial. Intensive Care Med 2017;43(11):1551-61.

74. Young P, Bailey M, Beasley R, et al. Effect of a buffered crystalloid solution vs saline on acute kidney injury among patients in the intensive care unit: the SPLIT randomized clinical trial. JAMA 2015;314(16):1701-10.

75. Semler MW, Self WH, Wanderer JP, et al. Balanced crystalloids versus saline in critically III adults. N Engl J Med 2018;378(9):829-39. 
76. Krajewski ML, Raghunathan K, Paluszkiewicz SM, et al. Meta-analysis of highversus low-chloride content in perioperative and critical care fluid resuscitation. Br J Surg 2015;102(1):24-36.

77. Myburgh JA, Finfer S, Bellomo R, et al. Hydroxyethyl starch or saline for fluid resuscitation in intensive care. N Engl J Med 2012;367(20):1901-11.

78. Khan UA, Coca SG, Hong K, et al. Blood transfusions are associated with urinary biomarkers of kidney injury in cardiac surgery. J Thorac Cardiovasc Surg 2014;148(2):726-32.

79. Kindzelski BA, Corcoran P, Siegenthaler MP, et al. Postoperative acute kidney injury following intraoperative blood product transfusions during cardiac surgery. Perfusion 2018;33(1):62-70.

80. Koch CG, Li L, Sessler DI, et al. Duration of red-cell storage and complications after cardiac surgery. N Engl J Med 2008;358(12):1229-39.

81. Mazer CD, Whitlock RP, Fergusson DA, et al. Restrictive or liberal red-cell transfusion for cardiac surgery. N Engl J Med 2017;377(22):2133-44.

82. Chen QH, Wang HL, Liu L, et al. Effects of restrictive red blood cell transfusion on the prognoses of adult patients undergoing cardiac surgery: a meta-analysis of randomized controlled trials. Crit Care 2018;22(1):142.

83. Steiner ME, Ness PM, Assmann SF, et al. Effects of red-cell storage duration on patients undergoing cardiac surgery. N Engl J Med 2015;372(15):1419-29.

84. Szekely A, Levin J, Miao Y, et al. Impact of hyperglycemia on perioperative mortality after coronary artery bypass graft surgery. J Thorac Cardiovasc Surg 2011; 142(2):430-7.e1.

85. Han HJ, Lee YJ, Park SH, et al. High glucose-induced oxidative stress inhibits $\mathrm{Na}+$ /glucose cotransporter activity in renal proximal tubule cells. Am J Physiol Renal Physiol 2005;288(5):F988-96.

86. Desai SP, Henry LL, Holmes SD, et al. Strict versus liberal target range for perioperative glucose in patients undergoing coronary artery bypass grafting: a prospective randomized controlled trial. J Thorac Cardiovasc Surg 2012; 143(2):318-25.

87. Umpierrez G, Cardona S, Pasquel F, et al. Randomized controlled trial of intensive versus conservative glucose control in patients undergoing coronary artery bypass graft surgery: GLUCO-CABG trial. Diabetes Care 2015;38(9):1665-72.

88. Lazar HL, McDonnell M, Chipkin SR, et al. The Society of Thoracic Surgeons practice guideline series: blood glucose management during adult cardiac surgery. Ann Thorac Surg 2009;87(2):663-9.

89. Leaf DE, Christov M, Juppner H, et al. Fibroblast growth factor 23 levels are elevated and associated with severe acute kidney injury and death following cardiac surgery. Kidney Int 2016;89(4):939-48.

90. Holmannova D, Kolackova M, Kunes P, et al. Impact of cardiac surgery on the expression of CD40, CD80, CD86 and HLA-DR on B cells and monocytes. Perfusion 2016;31(5):391-400.

91. Leaf DE, Body SC, Muehlschlegel JD, et al. Length polymorphisms in heme oxygenase-1 and AKI after cardiac surgery. J Am Soc Nephrol 2016;27(11): 3291-7.

92. Yared JP, Starr NJ, Torres FK, et al. Effects of single dose, postinduction dexamethasone on recovery after cardiac surgery. Ann Thorac Surg 2000;69(5): 1420-4.

93. Rahman IA, Mascaro JG, Steeds RP, et al. Remote ischemic preconditioning in human coronary artery bypass surgery: from promise to disappointment? Circulation 2010;122(11 Suppl):S53-9. 
94. Candilio L, Malik A, Ariti C, et al. Effect of remote ischaemic preconditioning on clinical outcomes in patients undergoing cardiac bypass surgery: a randomised controlled clinical trial. Heart 2015;101(3):185-92.

95. Zarbock A, Schmidt C, Van Aken H, et al. Effect of remote ischemic preconditioning on kidney injury among high-risk patients undergoing cardiac surgery: a randomized clinical trial. JAMA 2015;313(21):2133-41.

96. Sisillo E, Ceriani R, Bortone F, et al. N-acetylcysteine for prevention of acute renal failure in patients with chronic renal insufficiency undergoing cardiac surgery: a prospective, randomized, clinical trial. Crit Care Med 2008;36(1):81-6.

97. Mannacio VA, Iorio D, De Amicis V, et al. Effect of rosuvastatin pretreatment on myocardial damage after coronary surgery: a randomized trial. J Thorac Cardiovasc Surg 2008;136(6):1541-8.

98. McGuinness SP, Parke RL, Bellomo R, et al. Sodium bicarbonate infusion to reduce cardiac surgery-associated acute kidney injury: a phase II multicenter double-blind randomized controlled trial. Crit Care Med 2013;41(7):1599-607.

99. Lemma MG, Coscioni E, Tritto FP, et al. On-pump versus off-pump coronary artery bypass surgery in high-risk patients: operative results of a prospective randomized trial (on-off study). J Thorac Cardiovasc Surg 2012;143(3):625-31.

100. Mentzer RM Jr, Oz MC, Sladen RN, et al. Effects of perioperative nesiritide in patients with left ventricular dysfunction undergoing cardiac surgery: the NAPA trial. J Am Coll Cardiol 2007;49(6):716-26.

101. Sezai A, Hata M, Niino T, et al. Results of low-dose human atrial natriuretic peptide infusion in nondialysis patients with chronic kidney disease undergoing coronary artery bypass grafting: the NU-HIT (Nihon University working group study of low-dose HANP Infusion Therapy during cardiac surgery) trial for CKD. J Am Coll Cardiol 2011;58(9):897-903.

102. Cogliati AA, Vellutini R, Nardini A, et al. Fenoldopam infusion for renal protection in high-risk cardiac surgery patients: a randomized clinical study. J Cardiothorac Vasc Anesth 2007;21(6):847-50.

103. Lahtinen P, Pitkanen $O$, Polonen $P$, et al. Levosimendan reduces heart failure after cardiac surgery: a prospective, randomized, placebo-controlled trial. Crit Care Med 2011;39(10):2263-70.

104. Hajjar LA, Vincent JL, Galas FR, et al. Transfusion requirements after cardiac surgery: the TRACS randomized controlled trial. JAMA 2010;304(14):1559-67.

105. Murphy GJ, Pike K, Rogers CA, et al. Liberal or restrictive transfusion after cardiac surgery. N Engl J Med 2015;372(11):997-1008. 